Alicja Jagielska

Dariusz Markowski

\title{
Falsyfikat dzieła sztuki w wybranych orzeczeniach sądów polskich i niemieckich
}

$\mathrm{F}$ alsyfikat dzieła sztuki - to sformułowanie wywołuje zawsze dreszszandów oraz dyrektorów muzeów. Stwierdzenie, że obiekt nie posiada cechy autentyczności, którą wcześniej mu przypisywano, wiąże się z wieloma skutkami natury prawnej i ekonomicznej. Warto jednak na wstępie opracowania przedstawić kilka istotniejszych definicji samego falsyfikatu. Słowo „falsyfikat” pochodzi od łacińskiego falsificus, czyli „sfałszowany”. Fałszowanie to nic innego jak „świadome naśladowanie dzieła sztuki określonego autora lub okresu, uprawiane przeważnie z chęci zysku poprzez sprzedaż takiego dzieła jako autentyku"'. Fałszerz stara się pracować tak jak artysta, którego styl powiela. Przedmiot sfałszowany jest wykonywany metodami i przy użyciu materiałów właściwych oryginałowi, czasem sztucznie postarzany, tak aby jak najmniej odbiegał od oryginału². Wielu artystów już za życia toczyło walkę z fałszerzami swych prac, np. Albrecht Dürer w 1659 roku³ ${ }^{3}$ W Polsce słynny był proces o fałszerstwo obrazów, jaki wytoczył oszustom w 1912 roku w Krakowie Julian Fałat.

Ciekawy przypadek fałszerstwa stanowi zafałszowanie, czyli dokonanie przeróbek w dziele polegających najczęściej na umieszczeniu bądź zmienieniu istniejącej już sygnatury autora ${ }^{4}$. W ten sposób dzieła

1 Słownik terminologiczny sztuk pięknych, red. K. Kubalska-Sułkiewicz, M. Bielska-Łach, A. Manteuffel-Szarota, wyd. 3, Warszawa 2002.

2 The Dictionary of Art, ed. by Jane Turner, t. XI, Grave 1996.

3 Lexikon der Kunst, Deutscher Taschenbuche Verlag, t. IV, Monachium 1996.

4 P. Sarzyński, Przewodnik po rynku malarstwa, Warszawa 1999, s. 86. 
nieprzypisane żadnemu autorowi, a pochodzące z określonego okresu czasu i utrzymane w podobnej konwencji mogą „udawać” oryginał. Mało wartościowe dzieła, sygnowane nazwiskiem mniej znanego lub zupełnie nieznanego autora, po usunięciu oryginalnej sygnatury i zastąpieniu jej nową lub jej przerobieniu na nazwisko znanego artysty, stają się dziełami o nieporównywalnie wyższej wartości. Kolejnym rodzajem falsyfikatu jest pastisz, polegający na zestawieniu fragmentów istniejących obrazów i stworzeniu z nich nowego dzieła w stylu fałszowanego artysty. Ten typ fałszowania dotyczy najczęściej twórczości artystów chętnie powielających motywy, jak choćby Jacka Malczewskiego, często malującego autoportrety nie tylko w różnych strojach, ale i na tle różnie kompilowanych pejzaży. Profesor Janusz St. Kłębowski wymienia też pseudofalsyfikat - „potencjalny oryginał lub wariant istniejącego materiału”. Pseudofalsyfikaty stanowią zatem stylizacje nieposiadające jako wzorzec żadnego konkretnego, realnego oryginału․ ${ }^{5}$ Obok dzieł sztuki i falsyfikatów istnieją też kopie, repliki i reprodukcje. Wszystkie te formy zawdzięczają swe istnienie oryginałowi ${ }^{6}$.

Wraz z powstawaniem wielkich kolekcji dzieł sztuki - zarówno państwowych, gromadzonych przez muzea, jak i prywatnych - rosła obawa przed fałszerzami. Z drugiej strony wzrost cen obiektów na rynku dzieł sztuki zachęcał kolejne pokolenia fałszerzy do uprawiania swojej działalności. Dla fałszerza największym wyzwaniem po opanowaniu techniki artysty i doborze właściwych materiałów było odpowiednie postarzenie dzieła, tak by pomyślnie przeszło tzw. test starości (badanie zabrudzeń powierzchniowych na licu i odwrocie, ocena zmian starzeniowych podobrazia, farb i werniksu, stanu zachowania i przyczyn zniszczeń) ${ }^{7}$. Fałszowanie to nie tylko odwzorowanie dzieła bądź

5 J. St. Kębłowski, Oryginał, replika, kopia, falsyfikat. Refleksje na temat kilku pojęć historii sztuki, w: Falsyfikaty dzieł sztuki w zbiorach polskich, Materiały międzynarodowej konferencji naukowej zorganizowanej 21-22 maja 1999 roku, Warszawa 2000, s. 294.

6 Ibidem, s. 291.

7 Warto zacytować: „Najpotężniejszym wrogiem fałszerzy jest czas” - pierwsze zdanie rozdziału zatytułowanego Granice sztuki fałszerzy, w: F. Arnau, Sztuka fałszerzy - fałszerze sztuki. Trzydzieści wieków antykwarskich mistyfikacji, Warszawa 1988, s. 231. 
stworzenie go w kompozycji typowej dla danego artysty, to także walka fałszerza $z$ materiałem i czasem, a do tego oprócz talentu potrzebny był zawsze spryt i wiedza praktyczna. Historie słynnych fałszerzy są najczęściej owiane tajemnicą. Bezspornie, najlepsi fałszerze to tacy, których jeszcze nie zidentyfikowano.

W polskich zbiorach pojawiały się i pojawiają falsyfikaty, często spory znajdują swój finał w sądzie. Do najbardziej medialnych falsyfikatów należy Zjawa, obraz przypisany przez eksperta w domu aukcyjnym Franciszkowi Starowieyskiemu. Zjawa - dzieło namalowane na zlecenie reporterów TVN i za zgodą artysty opatrzone fałszywą sygnaturą - zostało wystawione jako autentyczne na aukcję i sprzedane. Historia obrazu przeniosła się niebawem z mediów na salę sądową, gdzie wśród stron postępowania znaleźli się i dociekliwi dziennikarze, i pracownicy domu aukcyjnego. Do dziś pozostają niezakończone spawy zakupu obrazu Władysława Maleckiego i Leona Wyczółkowskiego. Przez długi czas na łamach prasy związanej z rynkiem sztuki pojawiały się doniesienia o toczącym się sporze pomiędzy domem aukcyjnym Agra-Art a nabywcą obrazu Władysława Maleckiego Pejzaż z oddziałem powstańczym.

W niemieckich zbiorach także pojawiały się falsyfikaty. Najczęściej wspominanym przykładem jest zakup obrazu Vermeera Chrystus i jawnogrzesznica - będącego w rzeczywistości autorstwa Hana van Meegerena - dokonany przez Hermanna Göringa, marszałka Trzeciej Rzeszy ${ }^{8}$. Właśnie fakt sprzedaży obrazu holenderskiego do kolekcji niemieckiej, co po 1945 roku stanowiło przestępstwo współpracy z wrogiem, doprowadziło do ujawnienia Hana van Meegerena jako fałszerza9 . Obecnie wykorzystując znawstwo warsztatu artysty, tj. wiedzę historyka sztuki oraz najnowocześniejsze metody takie jak badanie za pomocą odczynników chemicznych, podczerwieni, promieni ultrafioletowych, jesteśmy w stanie określić, czy mamy do czynienia z falsyfikatem, czy też nie. Coraz częściej w opracowaniach naukowych podkreśla się war-

8 F. Arnau, Sztuka fałszerzy - fałszerze sztuki, s. 304 i nn.

9 W okresie postępowania sądowego o życiu i twórczości H. van Meegerena informowały na bieżąco media europejski, a historię jego życia kilkakrotnie przenoszono na karty książek, np. F. Wynne, To ja byłem Vermeerem. Narodziny i upadek największego fałszerza XX wieku, Poznań 2008. 
tość i znaczenie współpracy historyków sztuki oraz konserwatorów dla pewności obrotu na rynkach dzieł sztuki ${ }^{10}$, chociaż, jak wyżej wspomniano, o wykryciu fałszerstwa nierzadko decydował zwykły zbieg okoliczności.

Poniżej zostaną przedstawione wybrane orzeczenia polskie i niemieckie ukazujące poszczególne problemy prawne związane z nabyciem falsyfikatu dzieła sztuki, m.in. zagadnienie dotyczące ekspertyzy dzieła sztuki oraz wyłączenia odpowiedzialności sprzedawcy. Niektórzy sądzą, iż ogólne przepisy dotyczące ważności czynności prawnej oraz odpowiedzialności z tytułu wykonania zobowiązania stanowią wystarczająca bazę prawną dla uczestników rynku dzieł sztuki. Praktyka państw zachodnich, w tym również Niemiec, pokazuje, że w przypadku transakcji z udziałem falsyfikatu dzieła sztuki to m.in. zastrzeżenia umowne w katalogach domów aukcyjnych, atrybucja dzieła zawarta w ekspertyzie, sama treść opisu katalogowego mogą wpływać, a nawet kształtować odpowiedzialność sprzedawcy dzieła nieautentycznego. W tej sytuacji przepisy dotyczące kontraktów pozostają dalekie od pożądanego przez uczestników handlu antykwarycznego wzorca i dlatego istnieje potrzeba wykształcenia się jednolitej linii orzecznictwa bądź też doktryny. Można tu przywołać wypowiedź Janusza Miliszkiewicza, zdaniem którego „prawnik, który chce się skutecznie zajmować problemami rynku sztuki, musi zdawać sobie sprawę, że nierzadko rynek ten przypomina walizkę iluzjonisty"11. I tak, by uporać się z wyzwaniami, które dostarcza nam do rozwiązania rynek sztuki, sądy bazując na obowiązującym systemie prawa, dokonywały wykładni zapisów ustaw oraz terminów używanych przy obrocie dziełami sztuki właśnie na potrzeby handlu antykwarycznego.

Niemiecki rynek dzieł sztuki, jako starszy i bardziej rozwinięty od polskiego, miał już od dawna do czynienia z falsyfikatami, a niejednokrotnie spory powstające wokół kupna dzieła o wątpliwej autentyczno-

10 D. Markowski, Ocena autentyczności dzieła na przykładzie wybranych obrazów polskiego malarstwa XIX i XX wielu, w: Ars Longa - Vita Brevis, Tradycyjne i nowoczesne metody badania dzieł sztuki. Materiały z sesji naukowej poświęconej pamięci profesora Zbigniewa Brochwicza, Toruń 2003, s. 267.

11 J. Miliszkiewicz, Katechizm każdego antykwariusza, „Art\& Business” 2008, nr 7-8, s. 107. 
ści były rozstrzygane w toku postępowań sądowych. Dla zobrazowania różnicy pomiędzy polskim a niemieckim rynkiem dzieł sztuki i praktyki w rozwiązywaniu spraw dotyczących nieoryginalnych obiektów będących przedmiotem handlu dziełami sztuki, warto podać, iż w okresie powojennym w polskim orzecznictwie Sądu Najwyższego mamy dotąd jeden wyrok z 18 listopada 1983 roku $^{12}$ zajmujący się problematyką nabycia nieautentycznego naszyjnika $\mathrm{z}$ pereł, a w niemieckim dorobku Reichgerichtshof, a następnie Bundesgerichsthof możemy odnaleźć kilkanaście podobnych orzeczeń.

$\mathrm{Na}$ wstępie rozważań warto przedstawić stanowisko Sądu Najwyższego zaprezentowane w powołanym wyżej wyroku, uznane wówczas za nowatorskie, dokonujące wykładni rozszerzającej art. 770 k.c. i oceniające świadczenie falsyfikatu jako niewykonanie zobowiązania. Sąd Najwyższy stwierdził, iż nie można mówić o wadzie fizycznej wtedy, gdy kupującemu została wydana rzecz inna aniżeli stanowiąca przedmiot transakcji, w takim bowiem przypadku: „wadliwość wykonania umowy jest dalej idąca aniżeli w wypadku, gdy kupujący otrzymał rzecz, jaką chciał nabyć, a jedynie o zmniejszonej wartości lub użyteczności”. Zdaniem Sądu Najwyższego: „nie powinno ulegać wątpliwości, że z dostarczeniem kupującemu innej rzeczy aniżeli objęta umową mamy do czynienia w razie sprzedaży falsyfikatu zamiast przedmiotu należącego do cennej biżuterii. Wydając taki falsyfikat, sprzedawca w ogóle nie wywiązuje się z obowiązku dostarczenia sprzedanej, tzn. ustalonej w umowie, rzeczy". Sąd uznał, że przepisy o rękojmi nie mają zastosowania, a nabywca będzie chroniony na podstawie przepisów o błędzie albo o nienależytym wykonaniu lub niewykonaniu zobowiązania. Podsumowując, falsyfikat dzieła sztuki i idąca za nim nieautentyczność nie może być pojmowana jako cecha dzieła sztuki, będąca jednocześnie jego wadą. Zgodnie z rozumowaniem Sądu Najwyższego, falsyfikat należałoby traktować jako odrębny przedmiot istniejący obok oryginału (rzeczywistego bądź też wyimaginowanego). Stanowisko zaprezentowane $\mathrm{w}$ wyroku jest przedmiotem trzech glos

12 Wyrok Sądu Najwyższego z 18 listopada 1983 roku opublikowany w OSPiKA 1985, z. 1, poz. 4. 
aprobujących: E. Łętowskiej ${ }^{13}$, A. Szpunara ${ }^{14}$ oraz M. Jodkowskiej ${ }^{15}$. A. Szpunar podkreśla, że nie mamy do czynienia z wadą, gdy zamiast oryginału obrazu dostarczono jego kopię. Podaje w glosie przykład obrazu rzekomo namalowanego przez Jacka Malczewskiego, dodając, iż w tym przypadku „nie można powiedzieć, że rzecz jest tylko wadliwa, gdy dzieło stanowi falsyfikat" (jest to sytuacja świadczenia innego obiektu, dzieła, a nie wadliwego przedmiotu umowy). Także w niektórych opracowaniach dotyczących handlu na rynku sztuki uznaje się świadczenie falsyfikatu w miejsce oryginału dzieła sztuki za świadczenie niewłaściwe ${ }^{16}$. Inne stanowisko zajmuje J. Stelmach w wywiadzie opublikowanym (dwadzieścia lat po wydaniu omówionego orzeczenia Sądu Najwyższego) na łamach czasopisma „Art \& Business”17. Uważa on, że w przypadku nabycia falsyfikatu podstawą roszczeń jest brak cech (tu: autentyczności), o których informował sprzedawca. Zatem należałoby wówczas stosować przepisy o rękojmi dotyczące wady fizycznej. Gdyby jednak dochodzenie roszczeń na podstawie rękojmi było już niemożliwe (upłynął rok od dokonania transakcji), nabywca może skorzystać z przepisów o niewykonaniu zobowiązania. Zdaniem Jerzego Stelmacha mamy do czynienia ze zbiegiem przepisów o rękojmi i o niewykonaniu zobowiązań. Podsumowując, takie rozumowanie prowadzi do uznania falsyfikatu, czyli braku autentyczności dzieła, za wadę fizyczną ${ }^{18}$. Orzeczenie Sądu Najwyższego rozwiązało jedynie część problemów istniejących na rynku dzieł sztuki. Ze względu na ciągły rozwój rynku dzieł sztuki w Polsce można sądzić, iż niedługo sądy zajmą się nowymi zagadnieniami. Potwierdzają to pierwsze doniesienia w prasie antykwarycznej o śledztwie w sprawie fałszywego

13 E. Łętowska, Glosa do wyroku Sądu Najwyższego z 18 listopada 1983 r., „Nowe Prawo” 1985, nr 1, s. 117.

14 A. Szpunar, Glosa do wyroku Sądu Najwyższego z dnia 18 listopada 1983 r., OSP 1985, nr 1, C 4.

15 M. Jodkowska, Glosa do wyroku Sadu Najwyższego z dnia 18 listopada 1983 r., OSP 1985, nr 12, C 226.

16 A. Grzywacz, Obrót dziełami sztuki, Warszawa 2004, s. 35.

17 M. Branicka Prawdziwe falsyfikaty. Rozmowa z prof. dr hab. J. Stelmachem, „Art \& Business” 2003, nr 9.

18 Por. D. Olejniczak, Zarys problematyki prawnej fałszerstw dzieł malarskich, w: Prawo muzeów, red. J. Włodarski, K. Seidler, Warszawa 2008, s. 84 i nn. 
obrazu Jana Cybisa i po raz kolejny poruszenie tematu statusu prawnego eksperta dzieł sztuki w Polsce, a dokładnie jego metod pracy i zakresu odpowiedzialności ${ }^{19}$.

Pogląd przestawiony przez prof. Jerzego Stelmacha reprezentowany jest także w systemie prawa niemieckiego. Należy podkreślić, iż przywołane poniżej orzeczenia stanowią jedynie część niemieckiego dorobku. Zdarza się, że stanowiska sądów są odmienne i różnią się przedstawioną argumentacją. Celem opracowania nie jest jednak ukazanie całości orzecznictwa niemieckiego, lecz jedynie przedstawienie tych wyroków, które są najczęściej powoływane i podzielane przez kolejne składy orzekające. W orzecznictwie niemieckim autentyczność, autorstwo dzieła sztuki, jego proweniencja uważane są za cechy (Eigenschaft), a tym samym ich brak - za wady (Mangel). Do typowych cech dzieła sztuki czy też zbiorów (kolekcja znaczków) zalicza się związki rzeczy z osobami (np. właścicielem była znana osobistość), dołączoną ekspertyzę potwierdzającą autorstwo, określenie czasu powstania (datowanie), a także technikę, w której zostało wykonane ${ }^{20}$. Pojmowanie autentyczności dzieła sztuki jako cechy potwierdzają wyroki w sprawach: litografii Hansa Thoma ${ }^{21}$, dzieła przypisywanego Alexejowi Jawlensky'emu ${ }^{22}$ oraz obrazów Adriaena van Ostade i Davida Teniers. W obu ostatnich przypadkach nabywca otrzymał obrazy, których oryginalność została potem zakwestionowana. W przypadku obrazu Jawlensky'ego przez syna malarza, a w sprawie obrazów Adriaena van Ostade i Davida Teniers - przez eksperta, który stwierdził, że obrazy były jedynie naśladownictwem stylów reprezentowanych przez tych artystów. Brak każdej z tych cech powoduje

19 J. Miliszkiewicz, Prokurator pomoże antykwariuszom, „Art \& Business” 2008, nr 9, s. 94. Por. W. Szafrański, M. Skąpski, Eksperci i ekspertyzy na rynku dziet sztuki, w: Wokót problematyki prawnej zabytków i dzieł sztuki, Poznań 2007, s. 27-53; A. Jagielska, D. Markowski, Eksperci i Ekspertyzy, w: Sztuka Polska i Antyki, „Art \& Business" 2007, nr 10, s. 12, część Kolekcjoner.

20 B. Thomsen, Käuferschutz bei Kunstauktionen Vergleich der Rechte Deutschlands, Frankreichs, der Schweiz und Perspektiven spezialgesetzlicher Regelungen in den U.S.A. Schriften zum deutschen und europäischen Zivil-, Handel-, und Prozessrecht, Bielefeld 1989, s. 72.

21 Wyrok Reichsgericht z 7 lipca 1926 r., RGZ Band 114, s. 239.

22 Wyrok Bundesgerichtshof z 15 stycznia 1975r., NJW 1975 H. 21, s. 970 i nn. 
zmniejszenie wartości dzieła (Wertminderung), a tym samym powstaje możliwość skorzystania z roszczeń odszkodowawczych. Trzeba zauważyć, iż ustawodawca niemiecki wyróżnia kilka sytuacji: pierwszą, w której sprzedawca zapewnił kupującego o autentyczności dzieła w sposób bezpośredni, drugą - gdy zapewnienie oryginalności wynikało pośrednio, np. z opisu dzieła oraz trzecią - gdy sprzedający takiego zapewnienia $\mathrm{w}$ formie oświadczenia woli bezpośredniego bądź też dorozumianego nie dał. Co więcej, o tzw. stillschweigende Zusicherung (zapewnieniu milczącym, dorozumianym) decyduje skład orzekający, analizując każdorazowo przedstawiony stan faktyczny. W zależności od konkretnej sprawy kupujący może powoływać się na niewykonanie zobowiązania i wówczas żądać odszkodowanie (Schadensersatz) czy też powoływać się na błąd przy jej zawarciu.

Jednym z najstarszych orzeczeń traktujących o uprawnieniach nabywcy falsyfikatu jest wyrok w sprawie obrazu sygnowanego przez artystę Hansa Thoma. Dwaj handlarze sztuką zawarli umowę sprzedaży, której przedmiotem była przemalowana litografia z sygnaturą powyższego malarza. Obie strony uważały, iż przemalowanie, jak i sygnatura pochodzą od Hansa Thoma. Po zawarciu umowy okazało się, iż przemalowania dokonał nieznany artysta, a Hans Thom był jedynie autorem podpisu. Reichgerichtshof uznał, iż w tym przypadku mamy do czynienia z wadą rzeczy, tj. Sachmangel. Stwierdzono wadę rzeczy oraz jednoczesne spowodowanie zmniejszenia wartości przedmiotu ${ }^{23}$.

W jednym z późniejszych orzeczeń Bundesgerichtshof ${ }^{24}$ uznał, iż brak zapewnionej przez sprzedawcę autentyczności, czyli tzw. zugesicherte Eigenschaft, może stanowić podstawę roszczenia $\mathrm{z}$ powodu niewykonania umowy. W powoływanej sprawie chodziło o zestaw mebli sprzedany za 13000 DM, który zgodnie z zamieszczoną w prasie reklamą miał mieć 150 lat. Sprawa trafiła do sądu, gdy okazało się, iż powstał on na początku XX wieku i nie są to meble Biedermeier, lecz w stylu Biedermeier. Zdaniem sądu, prawdziwość tudzież autentyczność przed-

23 B. Thomsen, Käuferschutz bei Kunstauktionen Vergleich der Rechte Deutschlands, Frankreichs, der Schweiz, s. 62.

24 OLG Frankfurt, wyrok z dnia 14 lipca 1981 r., 17 U 190/80, NJW 1982, H. 12, s. 651 . 
miotu (tutaj: kompletu mebli) może być traktowana jako zapewniona przez sprzedawcę, tj. zagwarantowaną cechą przedmiotu (w rozumieniu i zgodnie z przepisem art. 459 BGB) przez oświadczenie zawarte w ogłoszeniu. Opisując stan faktyczny, sąd stwierdził, że sprzedawca w ogłoszeniu zapewnił o prawdziwości i autentyczności towaru. Taka deklaracja, że przedmiot posiada określoną cechę, może być też dokonana w sposób dorozumiany. Przykładowo oświadczenie może być zawarte w odpowiedzi sprzedawcy na pytanie o istnienie określonej cechy, w szczególności, gdy zdaje on sobie sprawę, że kupujący może uzależniać wolę zawarcia umowy i cenę od tej poszukiwanej właściwości. Nieautentyczność jest uznawana jako brak - wada, ponieważ prowadzi do obniżenia wartości przedmiotu, a także jego idealnego znaczenia jako oryginalnego dzieła sztuki o określonym pochodzeniu. Dla zainteresowanego rzecz taka traci na znaczeniu. Wówczas nabywca może żądać anulowania umowy: odstąpić od umowy albo wnieść o zmniejszenie ceny. Odszkodowanie nie będzie wyłączone przez artykuł 460 ust. 2 (błąd popełniony przez niedbalstwo przez profesjonalistę - tu: Kunsthandlerin - przy zawieraniu umowy), ponieważ kupujący powołuje się na zugesicherte Eigenschaft. Autentyczność niezapewnioną przez sprzedawcę w sytuacji nabycia falsyfikatu należy traktować jako wadę zmniejszającą wartość przedmiotu.

Ważne w ustalaniu, czy mamy do czynienia z wadą rzeczy, są niejednokrotnie dodatkowe opinie, ekspertyzy wykonane w celu potwierdzenia pewnych cech przedmiotu, np. autentyczności. Często ich dołączenie do dzieła przesądza o przymiocie obiektu, którego poszukiwał kupujący. W przypadku, gdy w samej ekspertyzie jej autor wyraża wątpliwości co do konkretnej cechy, np. przypisania rzeźby określonemu artyście, wówczas ryzyko w tym zakresie ponosi sam kupujący (gdy wystawiający opinię jest pewien, iż obraz pochodzi z XVIII wieku, wówczas ta cecha jest objęta zugesicherte Eigenschaft). Specyficzna jest też rola samej ekspertyzy, określającej dzieło sztuki i potwierdzającej jego właściwości. W orzeczeniu z 28 czerwca 1972 roku Bundesgerichtshof ${ }^{25}$ przyjął, że fakt przypisania autorstwa obrazu konkretnemu artyście (w tym przypadku chodziło o obraz Petera Paula Rubensa), zawarty w eksper-

25 Wyrok Bundesgerichtshof z 28 czerwca 1972, NJW, H. 27, S.1658. 
tyzie wykonanej przez specjalistę w dziedzinie sztuki jest właściwością (Eigenschaft) tego obrazu. Zgodnie z poglądami i piśmiennictwem niemieckim, stosunki przedmiotu sprzedaży z otoczeniem są jego właściwościami, jeśli mają wpływ na przydatność i wartość rzeczy. Ponadto wymagane jest, aby właściwości te wywodziły się z samej rzeczy, trwały przez określony czas i nie były rezultatem okoliczności niezwiązanych $z$ rzeczą. W sporze jedna ze stron argumentowała, iż opinia nie pozostaje w bezpośrednim stosunku z rzeczą. Ostatecznie Bundesgerichtshof uznał, że ekspertyza wyróżniająca obraz spośród dzieł sztuki innych artystów spełnia wymagania określone dla właściwości przedmiotu. Ponadto podkreślono, że bez względu na wpływ, jaki jej treść wywiera na wartość dzieła sztuki, jest ona istotna dla nabywcy.

Sądy niemieckie zajmowały się kilkakrotnie problemem, jak daleko aukcjoner może wyłączyć swoją odpowiedzialność. Wyrok Bundesgerichtshof ${ }^{26}$ dotyczący ogólnych warunków umowy (Allgemeine Geschäftsbedinungen) uznał za zgodne z prawem wyłączenie przez aukcjonera odpowiedzialności za autentyczność i proweniencję dzieła sztuki, o ile nie była to tzw. zugesicherte Eigenschaft. Takie wyłączenia, zdaniem sądu, są powszechne i jeśli nie są one narzucone jednostronnie przez dom aukcyjny, to stanowią jedynie przejaw swobody umów. W sporze chodziło o dzieło sztuki opisane w katalogu pod pozycją 523 („Alexej von Jawlensky, Martwa natura z zielona butelka, 30000 - olej na kartonie naciągniętym na deskę - 49,5 x 53,5 cm. Oznaczenie pochodzenia z pracowni artysty nr 1309. - Czas powstania 1909. Potwierdzenie [autentyczności] sporządzone przez C.W."), a nabywcy wydano niesygnowany obraz znajdujący się na drugiej stronie (zdarzają się obrazy obustronne, co często jest następstwem przyzwyczajenia artysty, a niekiedy wynika ze zwykłej oszczędności). Chociaż zdaniem strony skarżącej nie nastąpiło spełnienie postanowień umownych ani wykonanie umowy (aliud pro alio), to sąd biorąc pod uwagę regulamin aukcji, orzekł, że strona nie może odmówić zapłaty. Trzeba dodać, iż niemieckie przepisy chroniące konsumenta nie obejmują umów zawie-

26 Wyrok BGH z 15 stycznia 1975 r., VIII ZR 80/73 Köln, NJW 1975, H. 21, s. 970. 
ranych na aukcjach ${ }^{27}$ i mających za przedmiot rzeczy używane, zatem tezy tego wyroku odnośnie do swobody umów i kształtowania treści regulaminów są w niemieckim systemie prawnym wciąż aktualne.

W wyroku Bundesgerichtshof z 13 lutego 1980 roku $^{28}$ sąd rozważył, pod jakimi warunkami opisy katalogowe dzieł sztuki mogą stanowić potwierdzenie, gwarancję cech sprzedawanego dzieła sztuki. Sąd stwierdził, iż licytant nie może uważać opisów za milczące zapewnienie o posiadaniu przez przedmiot określonych cech. Jeśli jednak licytant bierze udział w aukcji wyłącznie pisemnie i nie miał możliwości osobiście obejrzeć wystawianego dzieła sztuki, wówczas omawiane opisy stanowią dla niego jedyne źródło informacji o obiekcie. Nabywca dokonując zakupu, sugeruje się jedynie tymi danymi. Regułą jednak jest, że opisów katalogowych nie można traktować jako stillschweigende Eigenschaftzusicherung. W katalogach niemieckich podobnie jak w polskich prawie zawsze można znaleźć stwierdzenie, iż informacje zostały zebrane w sposób staranny i profesjonalny, ale prowadzący aukcję nie bierze odpowiedzialności za ich treść (Haftungsausschluss). Odmiennie potraktowano wcześniej opis katalogowy wraz z załączoną wzmianką o ekspertyzie w sprawie obrazu Jawlensky'ego i zakwalifikowano jako zapewnienie istnienia określonych cech przez sprzedawcę. Należy jeszcze raz podkreślić, że każdorazowo jest rozważany stan faktyczny danej sprawy, co może powodować inne rozstrzygnięcia prawne w pozornie podobnych sporach.

W ostatnich latach ujawniono kolejne falsyfikaty dzieł sztuki w zbiorach muzeów niemieckich. W trakcie realizacji projektu muzealnego Maltechnik des Impressionismus und Postimpressionismus w Wallraf-Richartz-Museum w Köln ${ }^{29}$ odkryto, iż przypisywany do-

27 W ustawie niemieckiej wprowadzającej dyrektywę 99/44/WE uchwaloną 25 maja 1999 r. przez Parlament Europejski i Radę w sprawie określonych aspektów sprzedaży i gwarancji na dobra konsumpcyjne korzystając ze swobody pozostawionej przez ustawodawcę europejskiego wyłączono ochronę konsumenta w sytuacji nabycie własności rzeczy używanej na licytacji publicznej.

28 Wyrok Bundesgerichtshof z 13 lutego 1980 r., NJW 1980, H. 30, s. 1619 i nn.

29 http://www.kunstmarkt.com/pagesmag/kunst/_id144285-/news_detail. html?_q=\%20 
tąd Claude'owi Monetowi obraz Am Seineufer bei Port Villez ${ }^{30}$ jest falsyfikatem. Badacze zakwestionowali autentyczność dzieła, wskazując m.in. na podmalowanie obrazu (nietypowe dla Moneta), kształt samego podpisu mistrza i warstwę patyny mającej imitować oznaki starzenia się obrazu ${ }^{31}$. Oprócz falsyfikatów znajdujących się w zbiorach muzealnych (Wallraf to muzeum obywatelskie, jedno z pierwszych tego typu $\mathrm{w}$ Niemczech, powstałe $\mathrm{z}$ zapisu testamentowego, a następnie finansowane przez kolejnego zapaleńca, zarządzane przez fundację), ujawniono także kilka przestępstw związanych z powstawaniem czy też wprowadzaniem w obieg falsyfikatów. Media relacjonowały postępowanie sądowe prowadzone przed Landgericht w Monachium, w którym 52-letni ekspert sztuki został oskarżony o oszustwo i sfałszowanie stu ośmiu rysunków Salvadora Dali. Przedsiębiorczy ekspert podrabiał podpis Salvadora Dali, a „tworząc” dzieła, korzystał z rysunków zamieszczonych w katalogach tego artysty ${ }^{32}$.

To wszystko świadczy, że falsyfikaty nadal pojawiają się na rynkach dzieł sztuki. Można nawet stwierdzić, iż poza już istniejącymi w prywatnych czy publicznych kolekcjach, na rynek ciągle wprowadza się nowe. Nie wiadomo, ile tak naprawdę dzieł uważanych za klejnoty kolekcji mogłoby mieć podpis podobny do tego w Los Angeles w J. Paul Getty Museum, widniejącego pod rzeźbą Kouros: „grecki, pochodzący z 530 r. p.n.e. lub współczesny falsyfikat"33. Bez wątpienia dotychczasowe orzecznictwo niemieckie w zakresie sprzedaży falsyfikatu dzieła sztuki jest pomocne i stanowi podporę dla kolejnych składów orzekających. Ponadto wyjaśnienie kwestii autentyczności jako cechy, ekspertyzy załączonej do dzieła stanowiącej jego właściwość, roli stwierdzeń zawartych w opisach katalogowych i ekspertyzie w znacznej mierze uła-

30 Am Seineufer bei Port Villez - „Brzeg rzeki Seine przy porcie Villez”, tłum. aut.

31 AFP, Monet in Kölner Muzeum ist eine Fälschung, Berliner Morgenpost z 14 lutego 2008 r. http://www.morgenpost.de/kultur/article566637/Monet_in_Koelner_ Museum_ist_eine_Faelschung.html

32 Dali-Experte muß als Fälscher vor Gericht, Berliner Morgenpost z 10 kwietnia 2006 r. http://www.morgenpost.de/printarchiv/kultur/article269048/Dali_ Experte_muss_als_Faelscher_vor_Gericht.html

33 Greek, about 530 B.C., or modern forgery (tłum. aut.). http://www.getty.edu/ art/gettyguide/artObjectDetails?artobj=12908. 
twia współczesne rozstrzyganie sporów. Rozwój polskiego rynku dzieł sztuki i liczba zawieranych transakcji sprawia, iż sądy będą zapewne jeszcze wielokrotnie zmuszone wypowiedzieć się odnośnie do problemów prawnych pojawiających się w obrocie antykami. Wzrastające zainteresowanie polskich prawników zagadnieniami rynku antykwarycznego pozwala sądzić, iż kolejne opracowania interesujące zarówno dla właścicieli domów aukcyjnych, kolekcjonerów, jak i przedstawicieli wymiaru sprawiedliwości trafią już wkrótce do księgarń. 


\section{Summary}

\section{Forged object of the work of art in Polish and German courts verdicts}

The article concerns a crucial issue for the Polish art market. It deals with the problem of buying a forged object and its legal consequences in the German law. Courts' verdicts presented in the article could probably change the way of perceiving this problem in the Polish legal system and point out new solutions for our still developing cultural property law. It is worth emphasizing, that purchasing a fake presents the greatest threat to the stability of the art market and is widely disputed in the foreign literature. 